\title{
Academic Librarianship: A Crisis or an Opportunity?
}

\section{Diane Granfield}

Ryerson University

\section{Mary Kandiuk}

York University

\section{Harriet Sonne de Torrens}

University of Toronto

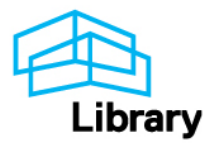




\title{
Academic Librarianship: A Crisis or an Opportunity?
}

\author{
Diane Granfield, BA, MLS \\ Head of Learning Services \\ Ryerson University Library \\ dgranfie@ryerson.ca
}

Mary Kandiuk, MA, MLS

Visual Arts, Design and Theatre Librarian

York University Libraries

mkandiuk@yorku.ca

Harriet Sonne de Torrens, MA, MISt, PhD, LMS

Visual Resource Librarian

University of Toronto Mississauga

harriet.sonne@utoronto.ca

\begin{abstract}
"Academic Librarianship: A Crisis or an Opportunity?" was a one day symposium held at the University of Toronto on November 18, 2011. The symposium provided a forum for stakeholders to consider recent troubling events and developments in the academic library community. The hiring of postdoctoral fellows at McMaster University to replace librarians, the strike by professional librarians at University of Western Ontario in 2011 and threats to the academic freedom of librarians at McGill University have all served as bellwethers and have been rich topics for debate of late. The symposium was intended to provide an opportunity to bring more coherence to the discourse and to consider further initiatives, increased activism, and to begin a process for providing greater leadership around issues relating to academic librarians and academic librarianship.
\end{abstract}

The day was organized around a series of panels. A number of key stakeholders spoke to specific themes: 1 ) the role of national and provincial labour organizations and local faculty associations; 2 ) trends and challenges in education and curriculum at library schools; 3) the role of library associations and professional accreditation; and 4) librarians on the front lines. The symposium emerged with a clear call to action: that it is time to become more pro-active in a collective manner, and to use the tremendous interest generated by this event as an opportunity to seek solutions to the challenges facing academic librarianship in Canada. There was overwhelming support for the creation of a virtual forum to continue the discourse and to bring in those who are interested and willing to become engaged but who were unable to participate in the symposium. 


\section{Keywords}

academic librarians; academic librarianship; collegiality; accreditation; library education; library associations; labour issues; unions; collective agreements; academic freedom; strikes; McMaster University; McGill University; University of Western Ontario; CLA; OLA; CAUT; OCUFA

Close to 200 individuals attended the symposium "Academic Librarianship: A Crisis or an Opportunity?" held at the University of Toronto on November 18, 2011. 'The Twitter feed (\#futurelibs) was lively and active throughout the day with participants reporting: "inspired, energized and proud to be part of this great community," "thought-provoking sessions," and "didn't know how hungry I was for this til it was in front of me." A grassroots initiative conceived and organized by the authors, the idea for a symposium relating to academic librarianship was sparked by a number of growing concerns, including:

- The hiring of postdoctoral fellows in academic libraries in positions traditionally held by librarians (such as at McMaster University); the designation, or the appropriation, of the title "librarian" in academic libraries by individuals without ALA accredited degrees but often with PhDs (such as at the University of California); the silent emergence of job postings in academic settings which require the skills and training of a librarian but don't acknowledge that they are librarians. All of these examples seem to suggest that the skills and competencies of academic librarians are not appreciated or recognized and a diminishment of the role and value of librarians in the academy.

- Troubling labour developments, in Ontario and elsewhere, which include the dismissal of academic librarians at McMaster University, attacks on the academic freedom of academic librarians at McGill University, and a recent strike by academic librarians and archivists at the University of Western Ontario.

It was felt that there was a need to:

- Provide an opportunity for stakeholders (such as library schools, library school students, library associations, academic librarians, academic library directors, and academic librarian union leaders) to discuss the threats to, and explore avenues for advancing, academic librarians and academic librarianship.

- To give voice to some of the case studies where actions seemingly at odds with the tenets of academic librarianship are playing out and explore their meaning, underlying causes and implications for stakeholders, and

- To begin a process for providing greater leadership around issues relating to academic librarians and academic librarianship. 
Generating an overwhelming response from the academic library community, it was clear that the topic of the symposium had tapped into a profound need. It provided a unique opportunity to hear each other's concerns and together explore ways of moving forward at what appears to be a critical juncture in academic librarianship. Attendees came from across the country ranging from students - the future of academic librarianship - to a wide range of other stakeholders who have the power to shape and influence that future.

The symposium was organized around three main themes: library education and curriculum, the role of library associations and the value of professional accreditation, and labour issues. Speakers recruited from stakeholder groups, all of whom expressed a tremendous willingness to participate from the very outset, were distributed across four sessions relating to the different themes. It was anticipated that there would be a range of views: that there would be those who believe that academic librarianship is experiencing a very real and dire crisis that is being driven by economic and political pressures in the academy beyond our control; there would be others who may agree that there is a crisis but who would view it as a "crisis of opportunity" and who believe that academic librarianship needs to evolve in order to survive, and that we need to seize the day; and there would be yet others who, in the words of filmmaker and social activist Michael Moore, believe that librarians are "a thousand Mother Jones at the barricades" and that we should be "plotting the revolution." So, what emerged as the prevailing viewpoint, what were some of the most important lessons learned, and was a way forward revealed?

The first session, "Faculty Associations and National Labour Associations in Defense of Academic Librarianship," examined recent developments at Canadian universities threatening academic librarianship, and the role of faculty associations and the value of unionization for academic librarians. Panelists included Francesca Holyoke, Chair of the Canadian Association of University Teachers (CAUT) Librarians' Committee from the University of New Brunswick, and Constance Adamson, President of the Ontario Confederation of University Faculty Associations (OCUFA) and an academic librarian at Queen's University. There is a long history of unionization in academic work environments, we were reminded, and the crisis in academic librarianship is not a "crisis in the work" but rather a "crisis in the workplace."

- Financial concerns are driving the decision-making in universities and in academic libraries.

- Arguments for flexibility are resulting in greater control by administration and less participation by librarians as their responsibilities shift and change.

- In a unionized work environment grievances and collective bargaining can be used to effect change, and collective agreements can provide fairness, equity, a test of reasonableness as well as processes.

- Academic librarians can and must be proactive by getting involved in their faculty associations and with faculty issues. They should use all available governance bodies in their institutions (Senate, for example) by becoming engaged and learning how to exploit them. They should model their work on that of faculty by moving away from job descriptions and taking control of their own work. They 
should define the scope of professional practice in an effort to create one parallel to that of faculty.

The second session, "Current Trends in Library Education and Curriculum," explored the core skills and competencies needed by the next generation of academic librarians and how Faculties of Library and/or Information Studies are responding to changing demands and positioning themselves to fulfil these needs.

- Dr. Seamus Ross, the Dean of the iSchool at the University of Toronto, stressed that the iSchool was focused on education and not on the "skills development business," and that programs needed to be able to respond to the changing information landscape. Most importantly, academic librarians need to be "scholar-practitioners" and must strive to be on a par with their academic colleagues.

- Professor Siobhan Stevenson, also from the iSchool at the University of Toronto, emphasized the difference between academic librarianship and public librarianship, with the emphasis in academic librarianship on academic freedom and the mandates of research and teaching. Her research suggests that students are attracted to librarianship because they want to perform meaningful work that is socially relevant. Library school curricula should move away from traditional library paths and provide, at their core, instruction in critical information studies, policy studies, critical pedagogy, and the like. She also stressed the need for librarians to become more engaged and empowered and to use that responsibility of academic freedom, a theme that recurred throughout the day both in speakers' presentations and in audience responses.

- Dr. Gale Moore, University of Toronto (Emerita), founding member and former Director, Knowledge Media Design Institute, Tri-campus Scholarly Communication Group, University of Toronto Libraries, brought the perspective of someone with an MLS and a PhD who has held both the roles of academic librarian and faculty member. She expanded on what she saw as the "Five C's of Academic Librarianship for the $21^{\text {st }}$ Century": Change, Cost, Communication, Communities, and Collaboration. She stressed the need, in these times of "edubusiness" and the bottom line, to reinvigorate our understanding of our strengths and communicate our value: in supporting critical pedagogy, as collaborators and advocates in scholarly communications, and in further developing our research paths.

- Professor Sam Trosow, Faculty of Information and Media Studies, University of Western Ontario, challenged the all-inclusive ischool approach, with its performative emphasis, arguing against the shifting emphasis from public service to a more corporate approach. He spoke about the interrelationships between teaching, technology and the "critical imperative," the interweaving of theory and practice in a professional and scholarly context, with an emphasis on "ethical practices and social responsibility."

In the third session of the day, "The Roles of Library Associations and Professional Accreditation," we explored the increasingly thorny and controversial topic of whether library associations are meeting the needs of academic librarianship and also what 
those associations perceive as their role in supporting academic librarians and the profession.

- Karen Adams, President of the Canadian Library Association and University Librarian at the University of Manitoba, stressed that the CLA is not a "professional" library association; it represents libraries and not librarians. She acknowledged that it has not succeeded in being the "national collective" that it might have been, and that the current vision and mission of CLA may not be as coherent as desired. The goal of CLA, she stressed, is to stay on the side of libraries and the public interest with an emphasis on advocacy at the federal level. She also emphasized that the association is as strong and effective as its membership, and that membership involvement is key to the development of policies and standards. She also spoke to the issue of accreditation and its emphasis on the quality of the programs and their ability to engage the community of employers.

- Janice Mutz, President of the Ontario College and University Library Association (OCULA) and an academic librarian at Lakehead University, stressed that the Ontario Library Association (OLA), like CLA, is a membership driven organization, and that involvement in OLA provides a way for students to develop and acquire the experience that will prepare them for careers in academic librarianship.

- Robert Johnston, co-founder of the London Chapter of the Progressive Librarians Guild and an MLIS student at the Faculty of Information and Media Studies at the University of Western Ontario, provided a student perspective on the recent strike by academic librarians and archivists at the University of Western Ontario as well as academic libraries in a neo-liberal era. "Silence is not an option," and we need "one $21^{\text {st }}$, not nineteenth, century library association," he stressed.

- Finally, Michael Ridley, Chief Information Officer and Chief Librarian at the University of Guelph, declared, “It can't be a better time to be an academic librarian," and, "We need to have a debate, not a single voice when it comes to complex issues." He also recognized that, "Professional associations are archaic, and that we let them behave that way," and that we need to be actively involved in helping CLA become a more vibrant organization. He asserted that library associations at their best should offer a solid foundation for community of interest in the context of allowing for diverse voices in what he called our "neighbourhoods of ideas." He issued the charge "to go out there and lead and not retreat," and said, "It is time to move into new roles that are itching for our expertise."

In the final session of the day, "Academic Librarians on the Front Lines," we heard some of the first hand experiences of academic librarians working at institutions where academic librarianship has been, or is currently, under threat.

- Marc Richard, academic librarian at McGill University, described the long history of the struggle for academic freedom of academic librarians and the right to participate in academic activities at McGill University, the intervention of CAUT, and the eventual establishment of a Library Council. 
- Nick Ruest discussed the difficult road that led to unionization at McMaster University and the creation of the McMaster University Academic Librarians' Association in 2011, emphasizing the invaluable support of CAUT and fellow academic librarians.

- Kristin Hoffmann described the lessons learned during the recent strike by academic librarians and archivists at the University of Western Ontario, which included the value of taking risks and the importance of articulating their "value as academic librarians."

The last and final speaker provided a powerful conclusion to the day leaving us all with the message that the articulation of values is critical for academic librarians and academic librarianship and that the solution comes from within. The symposium emerged with a clear call to action: that it is time to become more pro-active in a collective manner and to use the tremendous interest generated by this event as an opportunity to seek solutions to the challenges facing academic librarianship in Canada. There was overwhelming support for the creation of a virtual forum to continue the discourse and to bring in those who are interested and willing to become engaged but who were unable to participate in the symposium. So, to that end, if you are an academic librarian and would like to become actively involved, please send an email to: librariansymposium@gmail.com!

\footnotetext{
' We are grateful to our colleagues for generously participating in this event and for the financial support of CAUT, OCUFA, the iSchool at the University of Toronto, the Ryerson University Faculty Association, the University of Toronto Faculty Association, the University of Western Ontario Faculty Association, the York University Faculty Association, the McMaster University Academic Librarians' Association, and the University of Manitoba.
} 